evolution of nature myths is all the other way. First, the observation of the natural object and then the myth, not first the myth and then the natural object without it. We, says Mr. Maunder, do not learn of the existence of the sea by 'removing the mythological features' from 'Old Father Neptune,' and we may be quite sure that the Jews did not do so either.

It may not be a whit more wonderful to find that the Hebrews did not borrow their religion from the Babylonians, purifying it of its mythological elements, than to believe that they did. But it is not less wonderful, and it seems to be the truth. Where they got it, and why it differed from the religion of the rest of the Semites, still remains a mystery.

But there is no doubt that it did differ. 'Alone,' says Mr. Maunder, 'amongst the ancient peoples, they "feared not the signs of heaven, at which the heathen are dismayed" (Jer $\mathrm{IO}^{2}$ ), and scofied at "the astrologers, the star-gazers, the monthly prognosticators" (Is $47^{1: i}$ ). And he quotes from Schiaparelli, and says: "Truly it is no small honour for this nation to have been wise enough to see the insanity of this and of all other forms of divination. Of what other ancient civilized nation could as much be said?'

\title{
- $\dot{\varphi} \div \frac{1}{\uparrow} \quad \cdots$

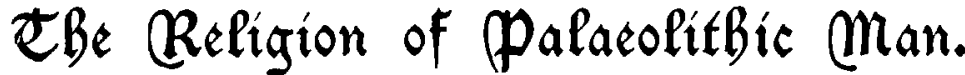

\author{
Br the Rer. J. A. MaCCulroch, Portree.
}

Palwolithic man, though primitive to us, was already far from being primitive, as compared with the 'hairy ancestor of arboreal habits,' or even his more obviously human successor who lived

\section{Long agn,}

In the mornings of the world.

Of that 'very besinning' we have no authentic information. The case is different with the men of the early stone age. We may surmise many things regarding their life and surroundings, based on more or less certain data. They could make tools and weapons, and use them; they clothed themselves in the skins of the animals they hunted; they decorated their persons with colouring matter, shells, bits of bone, even with beads. Latterly, they began to clomesticate animals - the horse, $\mathrm{dog}$, ox, and reindeer, - to make pottery (though this is not quite certain), and to cultivate cereals. They had bone needles with which to stitch together their skin robes. The art of the later palaolithic period is yet the wonder of archeologists, and each year adds to our knowledge of the power and skill in asthetics shown in that age. Sculpture, carving, engraving, and painting were all successively tried and excelled in; regular 'schools' of art seem to have existed, and the traditional methods of these 'schools' were handed on for ages.
With all this primitive civilization and this marvellous flourishing of the artistic instinct, was paleolithic man a religious being? A priori, in view of his other accomplishments, there seems little reason to deny him the comforts of religion. Many archæologists refuse to do so, but there are some who doubt, like M. Nortillet and Dr. Robert Munro. Even the ingenious Professor Pinsero, who finds religious sentiments and the beginnings of culture in the anthropoid apes, who, he says, worship serpents and bury them, placing a supply of insects in their 'graves' as a provision for the future life, refuses to believe that palkeolithic man had religion. ${ }^{1}$ But to him the modern analogues of the men of the stone age are the Eskimo and the Australians, who, ex leypothesi, are also nonreligious. We know, however, that the contrary is true of both these races, and if anthropoid apes have the faculty of worshipping 'pizen serpents,' it seems cruel to deny palieolithic man the faculty of worship. We shall see later that quaternary man may have worshipped the serpent.

Most writers on the origins of religion, if they attributed it to the men of the stone age at all, would credit them with little more than ghost,

'La psicologria dell" "omo pristorio. Palemo, is95. It would be interesting to know how far this statement has been corroborated by naturalists. 
or animal, or nature worship, or the practice of fetichisn and magic. M. Salomon Reinach, while insisting on the totemistic magico-religious rites of cave-man, thinks that he 'took no stock in gods' (se passait de dieux), because he could rule the forces of nature by magical powers and weapons. ${ }^{1}$ The priority of magic to religion is still a moot point; at all events, it is by no means certain that ghosts and animals and various natural objects were the first things worshipped, and are therefore among the origins of religion. And if magic did precede religion, was the latter evolved from it? Hardly ; for if magic se passail de dicux, where and when did the gods come in? There was no need of a deus ex machinu. Magic would seem to have supplemented rather than preceded religion, whether by priority or by natural evolution. But if, like Professor Pinsero, we take such races as the Australians, or Andamans, or Eskimo as the analogues of cave-man we shall at once find that he by no means se passait de di'ux. The Australians worship neither ghosts nor animals, though they are past masters in the practice of rather elaborate magical rites, but they do worship a deathless divinity, more or less anthropomorphic, it is true, and not envisaged as a spirit, but who is creator, moral governor, and future judge. The Australian Baiamai, or Dhuramoolin, or Bunjil, or Mungun-ngaur corresponds to the Andamanese l'uluga, also a creator, punisher of certain crimes, and judge of souls, and to similar 'high gods' of the lowest races elsewhere. Such races, though not primitive in the sense that palzolithic men were, were in the stone age when discovered, nor did they borrow these gods from missionary teaching. Had palreolithic man such 'high gods'? We cannot prove it, yet, judging by his modern analogues, he may quite well have possessed and worshipped them. In the rites of the worship of such divinities, the Australian uses a 'bull-roarer,' the whirring noise of which, when swung round, is frequently conceived as the voice of Baiamai, and which is talm to women, on pain of death. Two small articles in bone, one with serrated edge and with concentric circle decoration similar to that on Australian bull-roarers, were found at a quaternary station near Saint Marcel in France. ${ }^{2}$ They exactly resemble the bull-roarer in shape. The bull-roarer is always (except as a folk-lore survival) connected

I L'Anthropologit, xiv. 260.

Ibid. xiii. 152, xiv. 655 . with religious rites, in Australian, Red Indian, Melanesian, Greek, and a host of other ' mysteries.' By analogy, therefore, palieolithic man must have used his bull-roarer in similar rites, perhaps those of a 'high god.' Certain other mesolithic articles, in shape and in decorative motifs, exactly resemble Australian churinga. We shall return to these.

Analogy once more leads us to suspect that palæolithic man worshipped a female divinity. The earliest products of quaternary art are sculptures in 'round boss,' carved out of ivory, and found in layers immediately above those of the Mousterian epoch. Among these are nude female figures from Mas d'Azil and Brassempouy, representing, according to Judge Piette, two racial types -one, steatopygeous, suggesting a race somewhat like that of the Bushmen; the other, of a higher type, slender, and nearer the ordinary European." Were these somewhat realistic figures, unsurpassed in execution until the close of the bronze age, only studies of actual individual women, or even of the idealized feminine as it appeared to these very old masters? Some French archaologists have thought so, and have told us how the passion of love thus early impelled the artist to make an image of the adored one. On the other hand, the first known attempts at reproducing the human form since the days of the palieolithic artists are the menhir statues of La Marne and Pamproux, of the late neolithic or early bronze age, and the figurines in lead, but mainly in marble found in the \&gean area. The former indicate rather than copy the nude female form; they are of a conventional type, and, like the Mycencean figurines, are most certainly images of a gouldess, possibly, to judge from certain indications, of a goddess of the Aphrodite-Ishtar type. These early representations of the female form had a religious purpose; had the earlier palieolithic statuettes a similar purpose? Unless woman had a higher place in stone-age civilization than is usually assigned to her elsewhere, it is difficult to see why she and not the male figure should have been exclusively represented. Or did she lead the van of civilization, and was she the artist of these remote times? If, at this period, agriculture was beginning, and in any case through observation of the productiveness of the earth, it would have been a simple process to supply a concrete image of fertility, of the Earth as Woman-the Earth-mother, as was so common

\footnotetext{
"Ilidi. vi. 146 .
} 
in later times. The analogy of the menhirs of Gaul and of the . Egean figurines makes us think that the palieolithic statuettes represented not woman as woman, but a divinity in female form. Even the Australian makes temporary images of Baiamai out of earth for use in initiation ceremonies. Paleolithic man had a more lasting and a finer material-ivory; and he also had the artistic instinct in a high degree. We have yet to learn whether there was any artistic link between the ivory statuettes of Brassempouy and the marble figurines of the Egean. The connexion has been boldly suggested, nor, indeed, is it absolutely improbable.

But if palæolithic man had 'high gods' or goddesses, he must have addressed them in words of prayer. Of this there is naturally no record. But on the walls of the cavern of Altamira in Spain, so rich in wall paintings and engravings, are certain human figures wearing what seem to be animal masks, with some similarity to those worn by Red Indian shamans, as well as in totemistic dances. ${ }^{1}$ The arms and hands are almost invariably raised in front of the face, precisely in what is the conventional attitude of supplication everywhere. The attitude is quite evidently intentional. Have we here the representation of a masked medicine-man of the stone age, engaged in a religious rite, and supplicating the powers that be? It is certainly renarkable that the only human representations among crowds of animal paintings should bear this character.

Discoveries of late palceolithic interments, e.g. at Baoussés-Rousses, near Mentone, have raised the question whether the ghosts of the dead were worshipped. These, it is to be noted, are probably late palæolithic. Of the long period previous to that age we have no interments, and it has been boldly asserted, as by Mortillet, that the non-existence of funeral practices shows an entire lack of the religious sentiment, since 'the first result of every religious idea is to produce fear of death, or at least of the dead.' " 'The evidence of the Baoussés-Rousses interments shows, how-

1 L'Anthropologic, xr. 625 sq. 'Les l'eintures et Gravures Murales des Cavernes Pyrénćennes,' par E. Cartailhac et l'Abbé H. Breuil. A similar figure masked and with exaggerated phallus (as in most of these cave-paintings), engraved on bone, was found by Judge Piette at Mas d'Azil. Bulletin de la Societs de l'Anthropologie de Paris, 5e serie, t. iii. 1902.

"Arihcologic Préhistorifuci, p. 476 . ever, that other and earlier interments may yet be discovered. That we have not so far discovered them does not prove that palicolithic man left his dead lying casually about. He may have practised tree-burial, as do certain Australians and Red Indians; this would leave no traces for subsequent archroologists. He may have eaten his dead relations, and the custom might easily have already had a religious end, as it mostly has among low races where the flesh of relatives is eaten.

In considering prehistoric and other interments a distinction should be drawn between mere care of the dead, indicated by burial and nothing more, and worship of the dead man, who is supposed to be placated or made propitious by gifts or through other rites of which evidence may or may not exist. Actual worship, as well as the belief in a future life, seens to be indicated by the Baoussés-Rousses and other interments.

First may be mentioned the treatment of the corpse. It was deprived of the flesh before burial. This dicharnement is practised by many savage races, as it was in neolithic times, either by exposing the corpse or by its temporary burial, or by some artificial method more or less careful. The latter was the method adopted in these palxolithic interments, and that it had been extremely careful is incicated by the fact that, in general, the bones remain in their natural connexion, united by their ligaments. What the precise object of this dechtrmenent is, or was, is not clear. In some cases it is done in order that the bones may be carried about in the wanderings of the tribe, or preserved in some sacred place. Some other purpose must underlie the cases in which they are subsequently interred. Possibly it may be connected with ideas of the revival of the life, the bones being regarded by some races as the seat of life.

Second, the bones being thus laid bare, they were coloured with some red pigment, probably red ochre. 'This was also a general custom in neolithic times, as is seen by interments in Egypt, Russia, Italy, France, and England, as well as among savages like the Andamanese, the Australians, and certain Red Indian tribes. The custom is primarily a continuation of the similar practice of painting the body while living. It is thus also intended that the deceased, beyond the grave, may be as he was on earth, and it may also possibly contain the idea of making him duly 
presentable to the gods, to whom, as in Australian belief, he now returns. Among the Red Indians certain kinds of corpse-painting are intended as a sign of respect to those who have shown themselves specially brave during life. Any or all of these ideas may have suggested the custom to palrolithic man, who certainly must have attached some definite meaning to the practice. Such painted palæolithic skeletons have been found at Mentone, Mas d'Azil, and in the Ain Department of France.

Thirdly, whatever idea was attached to the colouring of the bones, doubtless also attached to their decoration with shells. The Laugerie Basse male skeleton was covered with shells arranged in pairs on the skull, arms, legs, feet, etc. In this case, as in the Baoussés-Rousses interments, the skeleton, and not the corpse, had been thus adorned. Shells pierced, showing that they had been connected by some kind of thread, as in a necklet, were found round the neck, arms, legs, and on the skull, while two infant skeletons had similar shells at the waist, indicating a girdle or, perhaps, some kind of dress adorned with shells. In some cases the skeletons had been wrapped in or laid upon skins, as remains of skin and hair were found beneath them.

These extraordinary methods of treating the dead indicate extreme solicitude for their welfare, and, therefore, presuppose a belief in continuance of life beyond the grave. They also appear to suggest a worship of the dead, or, at all events, that fear of or reverence for the dead which gradually produced worship of the dead. The unusual care bestowed makes it probable that some intention of propitiating or of seeking the good offices of the dead was intended. If M. Mortillet's contention regarding the care paid to the dead in quaternary times be true, these methodical and ceremonial interments would then show a growing respect for the dead, and possibly a rising belief in them as worshipful objects. The funeral mobilier is certainly scanty, but this is also true of many neolithic interments, though we know that the dead were then certainly worshipped. Offerings of food would, naturally, show no traces of their presence. Did palrolithic man, then, believe in ghosts?

It is far from unlikely that long before the rise of the animistic philosophy through dreams and the phenomena of trance and death, with its consequent belief in and worship of ghosts, the dead were believed to be still living in the grave. Traces of this belief survive even among peoples who believe in a separate spirit-world, or who have accepted the Christian creed as to the future life. The dead man is frequently represented as coming in the flesh, not as a ghost, from the grave to visit the living, to feast with them, or even upon them. It is also suggested by the vampire belief. Thus, even if quaternary man knew nothing of animism, he may quite well have held that the dead lived on and were capable of doing him harm or good, and therefore to be treated accordingly. On the other hand, he may have been more or less animistic, or have, at all events, believed in some kind of 'influence' emanating from things or persons, or existing separately from them, like the Melanesian mana, or the Red Indian zeakan-essences which prove a surprising psychic imagining among savages.

Palreolithic man was a cannibal. He split the bones of the dead to obtain their marrow. Were these his own dead, or were they enemies? Probably the latter, if he buried his dead. The flesh of the former, when removed from the skeleton, as at Baoussés-Rousse, may also have been eaten. Australians who practise dicharnement on their relations usually eat the flesh and then give the bones honourable burial. They also, in some tribes, eat hostile blacks. But they do not eat the dead usually merely for food: they eat them for a variety of other reasons-frequently to obtain their strength or their soul. Their cannibalism has been affected by the animistic philosophy. Perhaps that of palaeolithic man, which seems to have resembled it, was also so affected.

The existence of animism is also suggested by some other relics of the quaternary period, if, as has been alleged, these are amulets. M. Piette asserts this of various small discs of bone with ornamentation, geometric or animal, and pierced at the centre. Others maintain that they were only a kind of button attached to one side of the primitive skin garment by a knotted cord! We have seen that the men of the period adorned themselves and their dead with shell necklets, armlets, and girdles, and abundant remains of these, as wcll as of serpentine pebbles, quartz crystals, pieces of bone, and teeth of animals, all pierced with one or more holes for suspension, have been found in quaternary stations. Some of these show traces of engraving. Were they simple ornaments, or, like most savage ornaments, 
were they also amulets? Quartz crystals found in neolithic graves were certainly amulets, as are the similar crystals prized so much by Australian medicine-men. An amulet presupposes animism, even though its modern wearer, savage or civilized, does not connect it with a spirit supposed to work through it, but only wears it for luck. The amulet is really, in origin, a fetich which is tenanted by a spirit at will, and a fetich is lineally descended from the animistic philosophy which held that all things had a spirit. These palæolithic discs, if they were amulets, thus imply an existing belief in animism.

Thus it is quite possible that quaternary man revered the shosts of the dead, and not merely the dead consiclered as still living in the tomb. Why has no palaolithic ghost appeared at a scimce to record his former history? Or do ghosts, as M. D'Assier believes, ${ }^{1}$ gradually vanish into thin air as time goes on, so that modern folk are haunted only by comparatively modern ghosts? This is a comforting theory, even if it debars us from the revelations of stone-age phantasms; for it would indeed be serious if, as De Quincey's brilliant brother supposed possible, a federation of the infinite generations of ghosts were to talie place at any time against a single generation of men!

Animal worship is suggested by the representation of the serpent. Generally speaking, palæolithic man's engraved or painted animals are realistic and not symbolic, and thus hardly point to a religious purpose, save in so far as M. Reinach suggests. Usually serpent-engravings are so true to nature that the species may be recognized. There is one exception found at Lorthet. On a piece of reindeer antler a serpent (viper?) is carved in relief. It is surrounded by an ornamental border in which the spiral is conspicuous. Does this prove a cult of the serpent in these remote ages: was the serpent already an object of superstitious terror; or is the whole but an instance of palzolithic man's love of ornamenting everything? On the whole, we incline to the evidence of a quasi-cult, especially when it is considered that in mesolithic times the serpent had already become a symbol, as is proved by the painted pebbles from Mas d'Azil with purely conventional renderings of some reptilian form. Among these symbols of a later age, most of them existing either as symbols or as

\footnotetext{
' see his L'Homme' Costhumi.
}

direct representations in the palaeolithic period, is that of a tree. It is far from unlikely that even then the tree was more or less an object of veneration, as it was also an object to be represented. During the glacial or subglacial epochs, when trees were scarce over the European area, they must have been highly valuable to man. And with primitive folk what is valuable becomes usually worshipful. With the increase of trees, especially such as supplied food, and with the beginnings of fruit-tree cultivation,-the evidence for which in late palreolithic times cannot be gainsaid,- such worshipful feelings would naturally increase. Trees have certainly been worshipped from a very remote period, as is pointed to by the universality of the practice, as well as by the presence of the tree in many myths of a high antiquity

Reference has already been made to the Australian churinga, wooden or stone objects with a design painted or carved upon them. With the Arunta these are individual possessions, guarded safely in the sacred place of the tribe, and each one is believed to have been dropped by an ancestral spirit when he incarnated himself for purposes of rebirth in a woman of the tribe. ${ }^{1}$ This remarkable philosophy has been evolved by the lowest savages. The designs, say Messrs. Spencer and Gillen, are purely conventional, zoomorphic or phytomorphic, and totemic. The Asilian pebbles exactly resemble them in shape, and many of the designs, like that of the bull-roarer already referred to, are nearly parallel to the Australian devices. Were they, then, totemic in character, and did they imply a corresponding spirit-belief? We have seen that palæolithic man believed in a future life. The likeness of Asilian pebbles and Australian churinga is therefore highly suggestive of a similar belief and purpose in both cases.

M. Salomon Reinach holds that the marvellous animal paintings of palæolithic age in the dark recesses of l'yrencan caverns must have had a magico-totemistic purpose. Only animals useful to man are represented, and on the theory of sympathetic magic the very representation gave man a hold over the animal represented. Some ritual, analogous to that of the Arunta for the purpose of increasing the totem species and hence the general food supply, may have been performed

${ }^{1}$ Spencer and Gillen, Natiz' Tribes of Central Australia. 
before them. The result would be twofold: to increase the productive powers of the animals, and to bring them, as it were, automatically within the hunter's reach. ${ }^{1}$ So savages make models of the fish or beast they hope to capture ; so Red Indians have imitative animal dances before the hunt takes place. This is all theory, but it is highly suggestive, although the similar. Bushman wall-paintings do not appear to have had this purpose. In some cases, however, the chief animal represented, which also gave its name to the Bushman cave, was the badge of the cave-group, totemic or otherwise. $^{2}$ The presence of the masked human figure in a supplicatory attitude among the quaternary cave-paintings may lend some support to the hypothesis. In M. Reinach's opinion palaolithic totemism was followed by domestication of certain of the totem animals, just as the cult of cereals was followed by their cultivation. In the grotto of Espélugues at Lourdes and at Bruniquel ears of barley sculptured in reindeer-horn have been found, and an engraving of the same plant was unearthed at Lorthet. ${ }^{3}$ Both are palazolithic, and if the men of the period had already found the food-value of cereals without necessarily cultivating them, they may quite likely have inaugurated a cult such as was used in archaic Greek ritual and survived in the mysteries at Eleusis. Cultivation of grain certainly existed in the Mesolithic (Asilian) epoch.

Did palreolithic man also worship the sun? In all ages and countries (e.g. in Egypt as a hieroglyph, in North America as a pictograph) a circle with rays proceeding from the centre to the circumference, or from the circumference outwards, has been used to represent the sun, and the symbol implies a worship of the solar orb. This symbol is found in mid-paleolithic layers at Gourdan and Mas d'Azil, and it is remarkable that it has been in use continuously from that time, on through the neolithic, into the bronze age in Gaul. In some instances (palreolithic) discs have been carved out of bone and ornamented with interior rays; utilitarians, as we have seen, say they are buttons! ${ }^{4}$ But precisely similar figures

\footnotetext{
1 L'Anthropologic, xiv. 260.

2 Stow, Native liaces of S. Africa, p. 32.

"Bertrand, La Gaule azant les Guulois, Appendix, p. 279.

+ Similar discs have occasionally geometric or animal figures engraved on them. See Mortillet, Music Prihist., Planche xxiii.
}

are engraved on reindeer antlers of the same epoch. The sun must have been most welcome to men living half-naked during a period of increasing cold which ended in great inundations, and where the instinct of worship was already developed, the sun-the most striking object in nature-would quite naturally be adored and, by artists, represented.

The circle represented the sun; what did the spiral symbolize? This is quite unknown to us, but its use over a widely extended area, in Egypt, and over the whole region influenced by the Egean culture, shows that it had a symbolic value. Egypt has generally been supposed to have been the centre from which the spiral motif spread outwards over all Europe, zia Mycenae. ${ }^{5}$ We have already found it engraved in conjunction with the serpent in paleolithic times, however, and concentric circles also occur on the bull-roarer. Other spirais of the same age have now been reported among M. Piette's discoveries, and they prove conclusively the existence and common use of this symbol in quaternary times. Both single and double spirals have been met with, while in one or two cases there is some attempt at representing a row of these ormamental figures. ${ }^{6}$

Symbolism thus began in the palrolithic age, and flourished side by side with realistic art. In the later ages, when the art tradition proper had been lost or hidden away in obscure comers, it grew apace and, hand in hand with conventional pattern, ruled the field. Could we but trace the religious value of these ancient symbols as we can those of the Wheel in Celtic paganism, or the Cross or Fish in Christianity, what a rich flood of light it would throw upon the beliefs of these early races! But the time for that has gone by for ever.

Enough has been said here to show how many things hint at a comparatively rich religious heritage possessed by man in quaternary times. $\mathrm{He}$ had high gods; he represented his divinities in artistic shape; he prayed to them; he worshipped the dead and believed in a future life; he may have been an animist; he certainly believed in magic, and probably was a totemist and venerated animals; he adored the sun and had already evolved a certain number of quasi-religious symbols. This is a formidable list of religious

\footnotetext{
- Goodyear, Grammar of the Lotus.

"See l'iette, Los Pyrintes pendant l'Age du Renue.
} 
beliefs with which to credit men whom we scarcely know save through their works. But who would have suspected that such a flourishing of art had existed in these backward ages, suggesting old masters and schools of art and traditional methods? If art existed, why not religion? Quaternary man, though primitive enough, was far from being primitive man, and since the days of that mysterious personage who, if certain anthropologists are to be believed, was a natural atheist and se passait de dicux, sufficient time had elapsed for religion to evolve itself. And perhaps primitive man had also his moments of religious insight and aspiration!

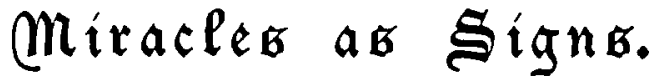

\section{By the Rev. A. Allen Brockington, M.A., Chilcompton Vicarage, Bath.}

'Christianity is immortal: it has eternal truth, inexhaustible value, a boundless future. But our popular religion at present conceives the birth, ministry, and death of Christ, as altogether steeped in prodigy, brimful of miracle;-aut miracles $d$, not happen.' These are familiar words of Matthew Arnold, to be found at the end of the $188_{3}$ Preface to Literature and Dogma. They still represent the convictions of many minds, not perhaps devout, but certainly not alienated from God. The intrinsic credibility of miracles is denied by men who profess great reverence for the 'teaching' of Christ. It is the 'teaching' of Christ that is immortal; it is the 'teaching' of Christ that has eternal truth. And those who have been concerned to defend miracles have, for the most part, done so for the sake of the 'teaching,' because miracles were a proof of the doctrine or essential to the proof of it. The evidential value of miracles has occupied chief attention. Mozley, in his rather unsympathetic Bampton Lectures, finds in the doctrine the cause of the change in the moral condition of mankind, and acknowledges that the doctrine has produced a new power of action, and, because this is so, goes on to find the paramount value of miracles in their evidence of doctrine. To inform us that the teaching was of divine origin and the commandments of divine obligation, miracles were performed. The inevitable consequence is that if miracles are successfully challenged-and the measure of success in the challenge is almost an individual matterthen the doctrine is discredited.

The question is whether it is the true view of miracles to regard them as chiefly valuable as 'proof' of doctrine, or essential to the proof of it. Miracles have to be regarded from the proper point of view if they are to be truly appreciated. Spinoza was preoccupied with the thought that they were interruptions of nature, and concluded that 'they cannot give us any knowledge of God, and that we cannot understand anything from them.' This thought of the 'interruption of nature' has led the modern critic to draw up a graduated scale of credibility-at the top of the scale those miracles that present the closest analogy to our own experiences, at the bottom of the scale such miracles as the Raising of Lazarus, because we can say of them that they 'do not happen.'

The biblical writer who had thought longest about miracles never calls them miracles. The invariable name in St. John's Gospel is 'sign.' Now, the chief value of a sign lies in what it points to. So that this name might be thought to support Mozley's contention that the chief value of miracles is evidential. But when we come to examine the 'signs' of St. John's Gospel we find that they are, in the language of the XXXIX Articles, 'effectual' signs-signs that carry their effect with them. And this fact is also clear in the Synoptic Gospels. When our Lord healed the paraly'sed man (Mk 21-12), He said to him, 'Child, thy' sins have been forgiven thee.' And when the Scribes accused Him in their hearts of blasphemy, Jesus said to them, "Why reason ye these things in your hearts? Whether is it easier, to say to the sick of the palsy, Thy sins have been forgiven thee; or to say, Arise, and take up thy bed, and walk? But that ye may know that the Son of man hath power on earth to forgive sins (he saith to the sick of the palsy), I say unto thee, Arise, take up thy bed, and go into thine house.' It is evident that the healing of the man's body did not so much support our Lord's claim to forgive the man's sins as actually symbolize the forgiveness. There was 